\title{
COVID-19
}

https://doi.org/10.17816/PED11323-40

\section{ANALYSIS OF THE COVID-19 EPIDEMIC: AN ADDITIONAL NARRATIVE; AN ALTERNATIVE RESPONSE}

(C) R.M. Rennebohm

St. Petersburg State Pediatric Medical University, Ministry of Healthcare of the Russian Federation, Saint Petersburg, Russia

For citation: Rennebohm RM. Analysis of the COVID-19 epidemic: an additional narrative; an alternative response. Pediatrician (St. Petersburg). 2020;11(3):23-40. https://doi.org/10.17816/PED11323-40

Received: 16.04 .2020

Revised: 14.05 .2020

Accepted: 23.06 .2020

According to the current prevailing narrative, the virus responsible for the COVID epidemic is exceptionally deadly and contagious - possibly as deadly, contagious and dangerous as the 1918 "Spanish flu" - and, in the absence of prolonged lockdown measures, has had the potential to kill a million or more people in the USA alone. At the other end of the explanatory spectrum a counter narrative has greatly minimized the threat posed by COVID and sees little need for major public health intervention or social change. A disciplined scientific analysis suggests an additional narrative that navigates a reasonable path between fear driven prescriptions and dismissive reassurance. This middle ground narrative suggests that the intrinsic deadliness of the COVID virus is above average when compared to many of the seasonal flu viruses of the past decade, but similar to that of the 2017-2018 flu virus, which killed an estimated 61,000 people in the USA. It also emphasizes that the intrinsic deadliness of many current social arrangements has contributed to "COVID deaths" and that there is need for major social change. This article suggests that neither the narrative of fear that prescribes excessive social control, or a narrative of dismissive reassurance that disregards need for fundamental social change, are based on good science. The article raises concerns that the prolonged lockdown/re-lockdown approach is misguided and likely to cause an enormous number of unnecessary deaths - both a greater number of cumulative COVID deaths, as well as "deaths of despair," deaths from worsening poverty and hunger, and deaths from inadequate attention for non-COVID health issues, particularly in disadvantaged communities and countries. An alternative response to the COVID epidemic is presented.

Keywords: COVID-19 epidemic; analysis; mortality; response.

\section{АНАЛИЗ ЭПИДЕМИИ COVID-19: ЕЩЕ ОДНО МНЕНИЕ И АЛЬТЕРНАТИВНЫЕ МЕРЫ РЕАГИРОВАНИЯ}

(C) Р.М. Реннебом

Федеральное государственное бюджетное учреждение высшего образования «Санкт-Петербургский государственный педиатрический медицинский университет» Министерства здравоохранения Российской Федерации, Санкт-Петербург

Для цитирования: Реннебом P.M. Анализ эпидемии COVID-19: еще одно мнение и альтернативные меры реагирования // Педиатр. - 2020. - Т. 11. - № 3. - С. 23-40. https://doi.org/10.17816/PED11323-40

Поступила: 16.04 .2020

Одобрена: 14.05 .2020

Принята к печати: 23.06 .2020

В соответствии с наиболее широко распространенным в настоящее время мнением, вирус - источник эпидемии COVID, является в высшей степени смертоносным и контагиозным - возможно, сравнимым по смертности, контагиозности и опасности с «испанкой» 1918 г. В случае непринятия мер по длительной изоляции вирус может быть причиной смерти до миллиона и более человек только в США. На противоположном конце спектра мнений опасность COVID считается невысокой и требует лишь минимальных вмешательств в политику общественного здравоохранения или изменений в социальной жизни. Научный анализ позволяет обосновать еще одно мнение, позволяющее наметить вариант ответных действий, кроме предписаний, основанных на страхе и на пренебрежительной уверенности. Этот вариант предполагает, что летальность от COVID в среднем выше, чем от большинства вирусов гриппа прошлого десятилетия, но равна таковой для вирусов гриппа 2017-2018 гг., явившихся причиной смерти около 61000 людей в США. Это мнение учитывает и то, что многие действующие социальные механизмы увеличивают летальность от COVID, и что есть необходимость существенных изменений в обществе. Данные, представленные в настоящей статье, свидетельствуют о том, что ни точка зрения, основанная на страхе и предписывающая избыточный социальный контроль, ни точка зрения пренебрежительной уверенности, игнорирующая необходимость фундаментальных изменений в обществе, не основаны на надежных научных данных. Статья иллюстрирует 
обеспокоенность тем, что тактика, основанная на длительной и повторной изоляции, является ошибочной и способствующей увеличению количества смертей - как за счет большего кумулятивного количества смертей вследствие COVID, так и за счет увеличения количества «смертей отчаяния» - смертей от прогрессирующих бедности и голода, а также смертей из-за неадекватного ведения больных, не инфицированных COVID, в частности в бедных общинах и странах. Представлены альтернативные меры реагирования на эпидемию COVID.

Ключевые слова: эпидемия COVID-19; анализ; летальность; меры реагирования.

"We are too much accustomed to attribute to a single cause that which is the product of several, and the majority of our controversies come from that."

Marcus Aurelius (Circa 1,840 years ago)

\section{FORWARD}

The main purpose of this analysis of the COVID epidemic is to share summarized scientific data, provide context and perspective, and offer reason for optimism. It is intended to lower excessive fears, raise spirits, provide clarity, reduce confusion, and appreciate the forest, while caring for each tree.

The intent of this analysis is to address the unhealthy division and polarization that has developed during this epidemic. This analysis seeks to walk people from the extremes into a middle ground where they can engage in respectful dialogue, understand each other, honor science, honor Humanity, constructively focus on the complex medical and social aspects of this epidemic, and collaboratively determine best remedy - using the disciplined problem solving approach practiced in both the medical clinic and the social clinic.

The aim of this analysis is to seek truth (whatever that truth might turn out to be) by raising questions, critically examining data and encouraging all plausible explanations for what has been noted during the COVID epidemic.

The goal is to create and restore social beauty and reverse a march toward its opposite.

\section{PROBLEM-SOLVING IN THE MEDICAL CLINIC}

In the Medical Clinic, physicians are disciplined to consider more than one narrative to explain a problem. Initially, one narrative (one hypothesis, one explanation) may seem most likely to be true, and one response may deserve top consideration, but other narratives and other possible responses are considered, if for no other reason to serve as a double check and to be thorough, out of an abundance of caution.

Physicians are also disciplined to test plausible hypotheses by carefully collecting and critically examining quality data. Dishonest data and data of poor quality must be recognized as such and avoided, lest they misguide. Anecdotal information is valued, too, but also needs to be carefully examined and placed into context. Quality data are preferred to incompletely examined anecdotal reports.
Physicians are disciplined to avoid jumping to conclusions and avoid viewing and presenting assumptions as though they are proven facts. Accuracy in language is important.

Physicians are disciplined to critically examine whether "what science tells us" and "what the experts tell us" is based on critical analysis of solid, ample, quality data (good science) or is based on sloppy, undisciplined "science" (poor science). "Follow the science" is good advice, but only if the science is properly done.

Failure to adhere to the above disciplined problemsolving approach often results in misdiagnosis, wrong treatment, and poor outcome.

Finally, good physicians recognize the importance of thorough, honest patient education and involvement of a fully informed patient/family in decision-making. Such education and involvement honor the patient and respect the patient's concerns and insights. The demystification and empowerment provided by such education provides needed perspective, is therapeutic, and leads to cooperation. Absence of such education typically leads to excessive and counter-therapeutic confusion, mystery, fear, anxiety, lack of cooperation, even hostility.

\section{A NARRATIVE OF FEAR}

The prevailing narrative about the COVID epidemic started with the assumption that this virus is exceptionally deadly and exceptionally contagious - possibly as deadly, contagious, and dangerous as the 1918 "Spanish flu" (which was due to an H1N1 Influenza A virus with genes of avian origin). This narrative included an assumption that $40-70 \%$ of the global population could become infected with the COVID-19 virus, and a fear that the mortality rate for those infected with COVID-19 might be somewhere between $1-4 \%$, possibly even higher $[3,17,18,25,26]$. The most widely quoted case fatality rate (CFR) was $3.4 \%$, which is 34 times higher than the most quoted fatality rate for seasonal flu $(0.1 \%)[17,18,25,26]$. It was also assumed, initially, that asymptomatic infection with COVID was quite uncommon. Based on these assumptions, the Centers for Disease Control (CDC) in the 
USA initially warned that COVID-19, if not adequately controlled, could kill millions of people - somewhere between 1.32-9.24 million in the USA and somewhere between 5.6-39.2 million people in China. The promoted narrative was that the COVID-19 virus is far more communicable, far more deadly, and far more serious than even the most severe recent seasonal flu viruses. A cornerstone of this narrative's response to the pandemic has been the rapid development of a vaccine, with plans to vaccinate most of the world's population.

The above narrative has continued to be the prevailing narrative, at least in the USA, Canada, and most of Europe. Although this narrative is still based primarily on assumptions and estimates, rather than solid scientific evidence, it is, still, constantly presented and portrayed as though it were "accepted, proven scientific fact". This accepted "fact" - that the COVID virus is so extraordinarily deadly and so exceptionally communicable that it will kill millions in the USA alone (or at least several hundreds of thousands), unless drastic control measures are taken - has led to a near total lockdown in the USA, Canada, most of Europe, and in most other countries of the world. This narrative has created tremendous fear, anxiety, and life-threatening hardships for billions of people.

In the beginning, it was conceivable that the above narrative of fear was accurate and wise. But, how accurate and how wise has it been, especially when one considers that a prolonged lockdown, by itself, might cause an enormous number of unnecessary deaths (a greater number of cumulative COVID deaths in the long run, as well as "deaths of despair", deaths from worsening poverty and hunger, and deaths from inadequate medical attention for non-COVID problems), particularly in already economically disadvantaged communities and countries? It is important to critically examine the above narrative, particularly the quality of the "science" and data behind it, and to consider other narratives and responses to the COVID epidemic. It is important to ask: to what extent has the prevailing narrative resulted from the disciplined problem-solving approach that has traditionally been practiced in the Medical Clinic?

A growing amount of scientific data and careful analyses (which will be detailed later) have cast doubts about the fear narrative - including the quality of its "science" and data and the wisdom of its preferred solution [5-7, $15,19,21,22,25,26,43,46,50-52]$. Unfortunately, powerful sponsors of this narrative have tended to proclaim challenges to their narrative to be "irresponsible", "dangerous misinformation/disinformation" and shameful "denial" of "what science tells us". That is not the way good science works or behaves. Excellent scientific problem solving considers more than one narrative; carefully distinguishes between assumption and proven fact; encourages formulation and testing of a variety of plausible hypotheses; seeks and respects a diversity of opinions; collects ample amounts of needed data; avoids jumping to conclusions; and values critical analysis of quality data over anecdotal reports, particularly inadequately examined anecdotal reports. Good science is open, humble, inclusive, and considers a spectrum of possibilities - not intolerant, shaming, narrow, and authoritarian. We must ask: Are other narratives closer to the truth and other responses wiser?

\section{A NARRATIVE OF NEGLECT}

At the other end of the spectrum is a narrative of dismissiveness, disregard, and neglect, which is best represented by Mr. Trump, who has shown little knowledge of, or patience with science; little honesty; little empathy or respect for the threats posed by COVID and seasonal flu, especially for people of color; little interest in optimally countering these threats; disregard for how certain social arrangements (e.g. racism and corporate capitalism) can contribute to human suffering and death; and little regard for human suffering in general.

\section{AN ADDITIONAL NARRATIVE; A SCIENTIFIC, PUBLIC-ORIENTED NARRATIVE}

In the medical tradition of critical thinking, disciplined scientific problem-solving, and social compassion, an alternative narrative is presented below. This narrative is based on what we have learned since the beginning of the epidemic, and what we have learned in the past about infection, epidemiology and immunology. It includes alternative responses that could have been chosen early on, subsequently, and now, as more information has become available.

In the beginning, it was appropriate to assume the worst and respond by encouraging at least a brief near-total lockdown (especially at the nursing home level), until more information was available. After all, this was a novel virus; it exploded onto the scene (in Wuhan); seemed to move fast; was rapidly causing a high number of deaths (particularly in the elderly); and little else was known at the time, including its origin. An "abundance of caution" was appropriate.

In addition to the initial lockdown measures, a first step (in the USA) would have been massive quality testing, not only of patients, but of the population at large (or at least of representative sub-populations) - using an accurate naso-pharyngeal swab PCR test to determine how many people (and which people) were currently infected (and infectious) and using an accurate blood antibody test to serially document how many people were cumulatively becoming infected as the epidemic unfolded.

Widespread use of the PCR test would have helped recognize who was an immediate threat to spread the 
infection and would have helped in contact tracing and determination of the true intrinsic communicability of the virus (the R0). Widespread PCR testing would also, of course, identify who was ill (so that they could be carefully, proactively, and superbly treated) and would make it possible to calculate a reasonably accurate case fatality rate (CFR). Of course, the PCR test would need to be accurate, with a minimum of false negatives and false positives.

The antibody test would have helped to serially tally the number of people and percentage of the general population that had become infected by the virus (the true denominator), which, in turn, would have helped to determine a true infection fatality rate (IFR), which is the best reflector of the intrinsic deadliness of the virus. Using both tests (the PCR swab and the antibody test) to evaluate health care workers (HCW) would have identified HCW who had developed immunity, were no longer contagious, and could work in the hospitals and nursing homes without being a definite threat to others and without fear of becoming infected themselves. (Granted, the extent and duration of immunity developed by those who have experienced actual infection has not yet been fully determined; but, most likely, those with antibodies will be well protected throughout the remainder of this epidemic.) The antibody test, of course, would need to be sufficiently sensitive, specific, and indicative of immune protection (i. e. reliable) in order to be helpful.

\section{Understanding "COVID deaths"}

An accurate CFR and IFR depends on establishing and applying accurate criteria for "definite", "probable", and "possible" COVID death, as well as "death not due to COVID, despite presence of incidental COVID test positivity or incidental exposure to COVID". This is a basic, fundamental principle of medicine and epidemiology. Unfortunately, uniform, strict criteria for "COVID death" have not been established and applied in the USA. Without wise uniform criteria and uniform application of them, it is impossible to know how many of reported "COVID deaths" are truly due to COVID - all of them, $75 \%$ of them, $50,25,10,125 \%$ ? Without an accurate COVID death count, an accurate IFR and CFR are impossible, and public health policy is impaired.

Making matters more complex, death from the COVID virus is not solely due to the intrinsic deadliness of the virus. The intrinsic deadliness of the health care system also plays a role. If the health care system is ill-prepared, does not have enough ICU beds, ventilators, negative pressure air-flow rooms, medicines, personal protective equipment (PPE), or knowledge about how to best treat severely ill COVID patients, and if access to health care is problematic (if it is unafford- able, or otherwise not promptly accessible to patients, e. g.), then prevention of preventable COVID deaths will not be as likely, and unnecessary deaths will occur. Those deaths are partly the virus's fault, but partly, and sometimes solely, the health care system's fault.

Furthermore, without adequate testing of health care workers (HCW) and without adequate provision of PPEs and negative pressure air-flow rooms, the hospital is contributing to the spread of the virus within the hospital itself. This spreading effect is compounded if certain hospitals are designated as "COVID-only hospitals" and receive a disproportionate number of cases. "COVID-only hospitals" would rapidly become iatrogenic "cesspools" of COVID virus, with large numbers of infected people spewing virus, resulting in extraordinarily high concentrations of COVID virus in the air and on surfaces. This would not only facilitate spread of the virus, but also put patients and $\mathrm{HCW}$ at risk of being exposed to extraordinarily large and dangerous inoculums (loads) of the virus - especially in the absence of sufficient PPE. Frequent inhalation of a large amount of virus is riskier than rare inhalation of only a tiny amount.

During a COVID epidemic, people with serious nonCOVID health problems are more likely to die, if access to services they need are less available (even shut down) while priority is being given to COVID. This can result in an above-average number of total community deaths - due to a combination of COVID deaths, usual non-COVID deaths (expected deaths, due to old age, e. g.), plus excessive non-COVID deaths caused by inaccessibility of usual health care. If some of those non-COVID deaths occur in people with incidental, unrelated COVID positivity or COVID exposure, it is highly misleading to include them in a "COVID death" count.

The point is that decisions made, regarding the health care system (before and during the epidemic), contribute to the intrinsic deadliness of the health care system, which, in turn, contributes to the likelihood of unnecessary deaths from COVID, increased nonCOVID deaths, and calculation of falsely high IFR and CFR for COVID.

The number of COVID deaths is also going to be higher if there is an inadequate effort or ability to promptly and aggressively treat the patients who develop severe versions of the disease. Fortunately, 98-99\% of people infected with COVID are either asymptomatic or do not feel sufficiently ill to warrant going to the hospital [19]. Study of COVID in Iceland revealed that $43 \%$ of people who had become infected with the COVID virus were asymptomatic [21]. Based on seroprevalence data, about $1 \%$ of infected people end up being hospitalized (primarily older people), 
which is comparable to the hospitalization rate of seasonal flu $(1-2 \%)[26,52]$. It is primarily the elderly who are dying from COVID $[26,52]$. In most countries, the median age of those dying of COVID is $80-84$ years [52]. It is deaths in nursing homes and assisted living facilities that account for $30-81.7 \%$ of all COVID deaths - e. g. $81.7 \%$ in Minnesota and $67.1 \%$ in Pennsylvania [52]. In a Swiss study, only $2.5 \%$ of COVID deaths occurred in people under age 60 , and the IFR of COVID infection of Swiss people under 60 was $0.01 \%$ [26]. (An IFR of $0.01 \%$ means that an infected person has a 1 in 10,000 chance of dying from that infection.) In New York City only $0.6 \%$ of COVID deaths were in people who were under age 65 and had no major co-morbidities [26].

It is only a small minority of COVID-infected people (outside of the very elderly, the already frail, and the excessively exposed health care workers) who are at risk of dying, and in these patients (as well as the higher risk patients) it is primarily immunemediated complications of the disease that cause death (e. g. "cytokine storm") [34, 39, 42]. It is likely that the very rare younger person who becomes extremely ill (despite absence of risk factors) does so because he/she is immunogenetically predisposed to wage an excessive immune reaction to the virus, especially when exposed to a large load of virus [27].

For several years rheumatologists have gained valuable experience in successfully treating cytokine storm, including viral-triggered cytokine storm [9, 31]. Such treatment must be prompt, innovative, aggressive, and careful, and is often life-saving. Unfortunately, this bold-but-caring approach has not been routinely used in the treatment of severe COVID (or for severe seasonal flu, for that matter). In fact, an aggressive treatment approach has been largely and openly discouraged (by the Infectious Disease Society of America and Italian NIH, for example) $[8,36]$. It is likely that many COVID deaths, especially in patients under age 65 , could be prevented, if immune-mediated complications were being treated more promptly and aggressively - i. e. if they were treated the way pediatric rheumatologists have learned to treat cytokine storm, immune-mediated microvascular endotheliopathy, and other life-threatening immune-mediated phenomena $[9,31]$.

In addition to the above intrinsic deadliness of the health care system, the intrinsic deadliness of the nursing home model can contribute to COVID death and the communicability of the virus (the R0). Large, crowded, understaffed (or poorly staffed) highrise nursing homes with no negative pressure air-flow systems and inadequate protective precautions can quickly become "hotbeds" for rapid spread of virus and exposure to large (and, thereby, more lethal) amounts of virus. Smaller, more spacious, well-staffed nursing homes, with negative air-flow systems and other proactive protective measures will experience fewer cases, less spread, lower inoculums, less severe disease, and fewer deaths.

In the midst of the COVID outbreak in northern Italy, the local government reportedly transferred noncritical COVID positive patients to nursing homes and paid those homes 150 euros $(\$ 160)$ per patient to receive these infectious patients [40]. This disastrous policy decision was not made by the virus. Similarly, during the outbreak of COVID in New York City, the Governor reportedly demanded that nursing homes accept COVID positive patients (presumably to prevent overloading of hospitals) [26], despite nursing home protestations that they were not adequately prepared to accept such patients.

Likewise, the intrinsic deadliness of a society's housing model also contributes to the IFR, CFR, and R0 of a virus. China's ultra-urbanization, with huge populations living on top of one another in close, congested high-rise apartment complexes (as in Wuhan) is a prescription for rapid, disastrous spread of virus, in high concentrations (loads, inoculums). The same is true of housing projects in many inner cities in the USA, where, incidentally, many low-wage health care workers live.

The COVID deaths have disproportionately occurred among people who are economically disadvantaged, have poor access to good health care and healthy food, live in congested high-rise tenement buildings, and work in crowded conditions (e. g. meat packing plants). People of color have been disproportionately affected by the COVID epidemic [33, 35, 38]. This points out that the intrinsic deadliness of our economic and social system (on top of an intrinsically deadly health care system that is even more deadly for people of color) plays a substantial role in causing death from COVID. COVID would cause far fewer deaths in a society with less poverty, free and accessible health care services, and better living, working, and social conditions.

So, COVID deaths (which are not being well-defined or accurately tallied) are not simply due to the intrinsic deadliness of the virus. The intrinsic deadliness of the health care system, nursing home model, general housing model, economic system, social system, and overall culture also play major roles. In combination, it is possible that these man-made factors are more deadly, and responsible for more deaths, than the virus itself. It is not just the virus that is killing people. Man-made social arrangements are increasing the likelihood of death from COVID (and from seasonal flu, for that matter), particularly in certain communities. 


\section{The Slow Roll-out of Testing}

Unfortunately, in the USA, testing was started slowly and has still been woefully inadequate and sometimes unreliable. Compounding the problem, many private-sector, for-profit lab testing companies have been hurriedly "vying for market share", and the quality of their various tests has been difficult to ascertain, often proven to be poor. A better response would have been to immediately and generously fund only a few highly trustworthy, not-for-profit, publicoriented, government funded labs to develop quality tests, preferably at public medical schools. Such a response could have included a governmental request that certain excellent private, for-profit labs freely share their expertise (including free access to their "intellectual property" and other "know how") with the public-oriented labs, for the good of the country.

As a result of the slow and poor-quality roll-out of testing, it is taking an unfortunately long time to accumulate quality data for accurate calculation of IFR and CFR, at least in the USA. Lack of testing also irreversibly smashed the brief window of opportunity to most accurately determine the COVID virus's true communicability (R0) and to base it on actual and ample field work. Instead, we quickly became reliant on gross estimates and complex, widely disparate $\mathrm{R} 0$ mathematical models that only the "mathematically gifted" can understand and critique. The slow roll-out has also impaired the ability of hospitals, nursing homes, factories, and densely populated communities to identify who is and is not a threat to infect others.

\section{What Have Quality Scientific Data Shown?}

Fortunately, data from several other countries in the world have contributed helpful information regarding the IFR and CFR of COVID. A recent review of 12 studies of the IFR and the prevalence of COVID antibodies in the general population revealed the following [26].

In 7 of the 12 studies the IFR for COVID ranged from $0.08 \%-0.2 \%$, which is similar to IFR calculations for seasonal flu [26]. In 3 of the 12 studies the IFR was a little higher, ranging from 0.28 to $0.5 \%$. In 2 of the 12 studies the IFR was between 0.02 and $0.04 \%$, which is lower than what has been calculated for seasonal flu. In the 12 studies, the percentage of people in the general population who were randomly tested for antibodies to COVID, and were positive, ranged from $0.133 \%$ (Rio Grande do Sul, Brazil) to $25.9 \%$ (Oise, France) [26].

The CFR for COVID has been calculated to be $0.15 \%$ in non-Hubei China [50] and has ranged from $0.07-0.3 \%$ in Singapore $[15,46]$. In Germany, the Infection Fatality Rate (IFR) has been estimated to be
$0.37 \%$ [51]. The just-mentioned CFRs are lower than the CFR measured for the seasonal flu viruses of 2017-2018 $(0.5 \%)$ and 2018-2019 (0.4\%) in Germany [41]. For comparison, the usually quoted (in fact, the exclusively quoted) CFR for seasonal flu in the USA is $0.1 \%$ (It is unclear, though, how truly accurate that $0.1 \%$ figure is, since it is based on mathematical models, assumptions, and estimates, rather than ample quality data).

Unfortunately, it has been difficult to establish a definitely accurate estimate of the intrinsic communicability (R0) of the COVID virus. The best window of opportunity to do so via actual field work and quality data collection was lost. This has resulted in R0 estimates that are based on gross assumptions and guesses. Initial WHO estimates of the R0 for the COVID virus ranged from 1.4-2.5. Liu reviewed 12 R0 studies of the COVID virus and found estimates ranging from 1.5-6.68, with a mean of 3.28 and a median of 2.79 [29]. For comparison, the estimated R0 for seasonal flu viruses has ranged from 0.9-2.1. Although most R0 estimates for COVID have suggested that the COVID virus is considerably more communicable than most seasonal flu viruses, some estimates have been within the R0 range estimated for seasonal flu viruses. On balance, it seems most likely that the COVID virus is more communicable than most seasonal flu viruses, possibly considerably more communicable - but, we really do not know. There is insufficient evidence to conclude that the COVID virus is enormously more communicable than most seasonal flu viruses. None of the R0 estimates for COVID suggest that it is even close to being as communicable as measles (R0 12-18) or smallpox. Current fears about communicability and the need for prolonged lockdown would certainly be appropriate and mandatory if we were in the midst of a smallpox epidemic (which was highly transmissible and carried at least a $30 \%$ mortality rate), but prolonged lockdown would be inappropriate if the true R0 of the COVID virus is only modestly worse than that of our worst recent seasonal flu viruses, and if the deadliness of COVID is comparable to the deadliness of our worst recent seasonal flu viruses.

The above data suggest that the COVID virus is not $10,20,30,34$, or 40 times more intrinsically deadly than seasonal flu viruses, as was initially pronounced at the beginning of this epidemic. Instead, the most sound data suggest that the COVID virus is about as deadly as our most deadly recent seasonal flu viruses.

Although anecdotal stories and media reports (from NYC hospital ICUs, e. g.) have been giving the impression that the COVID virus is far more intrinsically deadly than our most deadly recent seasonal flu viruses, there is insufficient quality scientific data and analysis to support this conclusion. Instead, it seems 
more likely that the intrinsic deadliness of the USA health care system and the intrinsic deadliness of the other social arrangements mentioned above have contributed greatly to the disturbing COVID experiences being reported in hospitals and ICUs.

For comparison, according to the CDC, the 20172018 seasonal flu killed 61,000 people in the USA, including 643 children, and it caused symptomatic infection of 11 million children [12]. Typically, about $83 \%$ of seasonal flu deaths occur during a three month peak of the epidemic, which means that during the peak of the 2017-2018 flu season about 533 children died of seasonal flu over the course of 84 days - about 6-7 children per day, on average, and much higher than that during the very peak of the epidemic. For comparison, in the USA, 8 children died from COVID between Feb 12 - April 28, 2020 (76 days), [49] while 81 children have died of seasonal flu during 2020, [49] prompting the authors [49] to state that "up to this time of the pandemic in North America, children continue to face a far greater risk of critical illness from influenza than from COVID-19" [49]. During the COVID epidemic in Wuhan, only one child died of COVID [16] (It is unclear whether co-morbidities contributed to that child's death).

We should point out that maybe annual deaths from seasonal flu would be much lower, if strict containment/ mitigation measures (near-total lockdown) were typically deployed during seasonal flu epidemics; and, maybe deaths from COVID would be much higher, if strict and prolonged containment/mitigation efforts had not been deployed for COVID. Containment/mitigation measures are certainly important and may help greatly to minimize deaths (in Wuhan, for example) during the early phase of an epidemic. But, the assumption that millions of people in China would have died (instead of the 4,634 that have actually died as of this writing), if strict and prolonged lockdown measures had not been deployed, is just that - an assumption, not a fact. The fear narrative presents that assumption as if it were proven scientific fact. But, it is more likely that the less-than-projected number of deaths in China has been due in great part to the COVID virus not being nearly as intrinsically deadly and as extraordinarily communicable as initially feared. Contrary to the fear narrative, we do not know how many deaths ultimately would have occurred in China, had prolonged lockdown measures not been deployed.

It will be important to follow what transpires over the long-haul in Sweden, where near-total lockdown has not been implemented. One year after onset of the epidemic, how will cumulative COVID deaths in Sweden compare to cumulative COVID deaths in the lockdown countries? Sweden's leading epidemiologists think the cumulative total in Sweden, one year from now, will be the same or less than totals in the lockdown countries [19].
It must be realized that seasonal flu is very communicable and can be deadly, especially when contracted by the elderly. According to the CDC, it claims the lives of 12,000-61,000 people in the USA each year, 41,000 on average - mostly older people with co-morbidities. Afterall, the deadly "Spanish Flu" of 1918 was an influenza virus. So, when the COVID virus is compared to seasonal influenza viruses, the seriousness of COVID is not being denied, minimalized, or trivialized. Both seasonal flu and COVID need to be taken seriously. Both are potentially deadly (mostly in the elderly and frail) and need to be managed carefully and wisely. In fact, for decades seasonal flu has not been taken seriously enough, and its most ill victims have been under-treated, under-studied, many dying unnecessarily (for the multiple reasons mentioned above and later).

A French study has suggested that the mortality rate of the COVID-19 virus may not be greatly different from that of the four common coronaviruses (HKU1, NL63, E229, and OC43), each of which can be quite deadly [43]. These four common coronaviruses cause $10-20 \%$ of respiratory infections worldwide, have a mortality rate as high as $0.8 \%$, and are responsible for many respiratory deaths each year (again, mostly in the elderly) [43]. The French authors point out that 2.6 million people usually die each year of respiratory infection, worldwide. In comparison, as of this writing (5/27/20) 355,736 people, worldwide, have died of COVID-19 (according to Worldometers) [55].

\section{Understanding Anecdotal Stories and Media Reports:}

But, if the COVID virus is not extraordinarily deadly (not more deadly than our worst recent seasonal flu viruses, and possibly not more deadly than some common coronaviruses), why, again, have the scenes in NYC ICUs (and elsewhere) been so alarming and shown so many patients and so many deaths, including deaths among health care workers? Why have there been so many alarming anecdotal reports, including ICU physicians saying that they "have never seen so many patients dying like this, and in these ways!" This discrepancy is extremely disturbing, and frightening, and begs thorough examination and understanding. Several factors may be involved.

It is possible (though not proven) that the COVID virus is exceptionally communicable and that this, coupled with the newness of the virus and its probable above-average deadliness (compared to average seasonal flu viruses), results in a more explosive and high-volume onset to its epidemic, with a rapid overloading of ill-prepared hospitals, ICUs, and nursing homes. Even if this is the case, the primary problem is the ill-preparedness of the hospitals and nursing homes. 
It is also possible that the over-loading of some hospitals with large numbers of severely ill COVID patients increased spread of virus within those hospitals (and beyond), increased the viral load (inoculum) in the air and on surfaces within those hospitals, and transformed those hospitals into "cesspools" of COVID virus - resulting in exponential escalation of disease and death within those hospitals, including among heath care workers. Spread of infection into the community is then increased when many of the lowest paid HCW go home to crowded tenement buildings further fueling the epidemic, exponentially so.

Furthermore, a chaotic and overwhelmed hospital work environment results in physicians working in a rush, with little time to think and perform at their best. Moreover, it is difficult for nurses and physicians to do their best work when they are encumbered by Hazmat-like PPE.

Another possible contributing factor would be delayed admission to hospital - i. e. "waiting until desperate" before going to the hospital. This would result in hospitalized patients already having severe, advanced disease by the time of admission. By definition, the best opportunity for early, prompt, life-saving intervention would often be lost for such patients. Many patients probably "waited until desperate" because they feared the cost of their hospitalization, or feared entering a COVID-infested hospital, or they did not want to burden the hospital until they were more certain that they probably had COVID, or it was otherwise difficult to access timely care.

If public policy was deliberately encouraging patients with suspected COVID to "stay home as long as possible" (so as not to overwhelm the hospital), this policy, by itself, would create losses of opportunity to provide early, prompt, life-saving care and would result in an excessively ill hospital population, and one that is spewing unusually large amounts of aerosolized virus. A fundamental principle of Medicine is the importance of providing early, prompt, anticipatory, and appropriately aggressive care.

Add to this the earlier-mentioned fact that severely ill COVID patients have not been routinely receiving aggressive treatment for the life-threatening immunemediated complications of this disease. This has resulted in excessive deaths - deaths that could have been prevented.

In addition to the intrinsic deadliness of the USA health care system (including undertreatment and delayed treatment of severe cases), the earlier-mentioned intrinsic deadliness of our nursing home model, general housing model, economic model, social system, and the USA culture (including racism) has undoubtedly contributed to creation of these alarming hospital and ICU scenes.
Finally, it is conceivable that severe cases of COVID are, on average, more severe and more complicated than severe cases of seasonal flu have been, especially when allowed to advance. We do not know if this is true, because ample, quality comparative clinical studies have not been done. Many of the alarming and "surprising" clinical aspects of COVID that ICU physicians have noted ("ground glass appearance" on CT, ARDS, "cytokine storm," myocarditis, myocardial depression, encephalopathy, microvascular endotheliopathy, coagulopathy, shock, and multiorgan failure, e. g.) have also occurred with past seasonal flu illnesses, but, perhaps, were not comparably noticed, or not as memorably noticed in those seasonal flu cases. If it is true, that cases of severe COVID are, on average, worse than cases of severe seasonal flu, this does not necessarily mean that the COVID virus is intrinsically more deadly than seasonal flu viruses. That is just one possibility. Another possibility is that the delay in hospitalization, mentioned earlier, has resulted in more severely ill patients. Another possibility is that patients with severe COVID have, on average, been infected with unusually large amounts of virus (for the reasons mentioned earlier), or it could be that the COVID virus sometimes evokes a greater immune over-reaction than do most seasonal flu viruses. Even if it is true, that cases of severe COVID are worse, on average, than most cases of severe seasonal flu, severe disease is quite treatable, though it is currently being undertreated and belatedly treated.

Further investigation, including rigorous investigative journalism, is needed to more fully and definitively explain the discrepancy between the IFR/CFR data and the frightening ICU scenes. To date, journalists have often presented frightening scenes and anecdotal reports without context or perspective, and have given the impression that these scenes are "proof" of the "obvious" extraordinary deadliness and extraordinary communicability of the COVID virus.

\section{CONCLUSIONS OF THE SCIENTIFIC, PUBLIC-ORIENTED ADDITIONAL NARRATIVE}

The paucity of quality data, the abundance of poor quality data (particularly the poor quality of daily "COVID death" counts), the frequent presentation of incompletely examined anecdotal information, and the lack of comprehensive analysis of the COVID epidemic, have made it difficult (particularly for nonphysicians) to comprehend the COVID epidemic. Determination of the intrinsic deadliness of the COVID virus has also been confounded by the need to fully appreciate the intrinsic deadliness of the health care system, nursing home model, general housing model, economic system, social system, and culture, as well as certain public policy decisions. 
Despite these difficulties, it is possible to draw scientifically sound conclusions about the COVID epidemic. Experience with the epidemic to date suggests the following:

- The COVID virus, like seasonal flu viruses (and common coronaviruses), can, absolutely, be deadly, primarily for elderly people, particularly people in their $80^{\mathrm{s}}$ and $90^{\mathrm{s}}$, especially for elderly people with co-morbidities, especially for elderly people living in substandard nursing homes, especially for the elderly in certain disadvantaged communities, especially for elderly people of color. It can also, but very rarely, be deadly in younger previously healthy adults whose immune systems are probably immunogenetically predisposed to react excessively to the virus, especially if such adults are exposed to large quantities of the virus - but, these life-threatening immune-mediated complications can often be successfully treated, if treatment is sufficiently prompt, aggressive, imaginative, innovative, and careful.

- Fortunately, the vast majority (98-99\%) [19] of people infected with the COVID virus do not require hospitalization, most are either asymptomatic (up to $43 \%$ ) [21] or experience only mild-moderate disease, and the risk of death is very low in ordinarily infected individuals under age 60 (an IFR as low as $0.01 \%$ - i. e. 1 in 10,000), particularly if they have no co-morbidities $[26,52]$. These actual data suggest that the true IFR and true CFR of COVID are relatively low - probably above-average, when compared to many of the seasonal flu viruses of the past decade, but similar to that of the 2017-2018 seasonal flu virus (which most people do not remember).

- Media reports and anecdotal stories (e.g. from NYC ICUs) have given the impression that COVID might be substantially more intrinsically deadly than the deadliest of our recent seasonal flu viruses. But, it is more likely that these dire ICU scenes are reflections of the intrinsic deadliness of the health care system and the intrinsic deadliness of the other social arrangements mentioned earlier.

- It is possible that severe cases of COVID are more severe, on average, than severe cases of seasonal flu, but this is unclear, because quality comparative data are unavailable. If this is true, the difference could, in great part, be because COVID patients with severe disease have been treated in a delayed fashion, and/or have been infected with larger amounts of virus, and/or because, in some patients, the immune system's over-reaction to the novel COVID virus might be greater than the over-reaction seen with more familiar seasonal flu viruses - but, severe immune over-reactions are treatable. (Though such treatment is not being routinely provided.)
- Patients with severe COVID have had several clinical features that have "surprised" their physicians. But, many of these features have occurred in past years with seasonal flus and have been seen in the context of other viral infections - though possibly not as frequently or to such a great degree (comparative data have not been adequately collected, so we don't know); possibly often not noticed or solidly remembered when they have occurred with these other viruses. It should be realized that COVID has received far more attention and has been studied in far greater detail than has seasonal flu. One lesson the COVID experience is teaching us is that, for decades, we have not given victims of seasonal flu the full attention, study, and aggressive treatment they have needed and deserved.

- The COVID virus might be more contagious than most of the seasonal flu viruses of the past decade (this is still unclear), but probably not enormously so. The fact that up to $43 \%$ of infected people are asymptomatic suggests that spread of the virus is not necessarily to be feared, as long as the most vulnerable are adequately protected.

- In the USA the number of COVID deaths is undoubtedly greatly increased because of the intrinsic deadliness of the health care system and the intrinsic deadliness of the nursing home model, the general housing model, the economic model, the social model, and the culture (including racism). If decisions were made to create "COVID-only" hospitals, this decision might be responsible for even more deaths. Delayed treatment and undertreatment of life-threatening immune-mediated complications of COVID has also likely contributed to increased COVID deaths. Failure to adequately protect residents of nursing homes, residents of high-rise inner-city housing projects, and workers in crowded factories has also contributed to COVID deaths. Correction of these man-made contributing factors could greatly reduce the number of true COVID deaths.

- Because uniform criteria have not been established (and applied) for what constitutes a "definite", "probable", "possible", or "non-COVID" death, we do not know what percentage of the reported "COVID deaths" are truly COVID deaths. Is it $75 \%, 50 \%$, $25 \%, 10 \%$ ? It is impossible to know with any certainty. This failure is indicative of poor science and poorquality data. This has affected the accuracy of the IFR and CFR calculations, has made accurate comprehension of the epidemic very difficult (especially for non-medical people), and has affected the quality of public policy. It has added to the mystery, confusion, fear, anxiety, hostility, controversy, polarization, and lack of cooperation surrounding this epidemic. 
- Judging by the extremely poor quality of the "COVID death" count data, the failure to promptly collect other needed data, the failure to consider more than one narrative, the failure to adequately test the prevailing narrative (and study the side effects associated with it), and the failure to consider all plausible explanations for observed phenomena -the prevailing fear narrative does not appear to be based on good science or good data. Although the fear narrative purports to be "science-based", it has violated many of the most basic, fundamental, and important principles of scientific problem-solving.

- The narrative of neglect is not based on science at all and has shown little interest in the many man-made social arrangements that have contributed to "COVID deaths" and non-COVID death and suffering.

- The fear narrative has been promoted by media that have violated basic, fundamental principles of investigative journalism - as evidenced by the fact that much of the reporting by conventional media has been sensationalistic and has not provided context, perspective, or thorough examination of all plausible explanations for the phenomena being reported. The media have focused on creating, heightening, and maintaining fear and worry.

- In short, the narrative of neglect is not based on science or on social responsibility. The fear narrative is not based on good science and is being promoted by journalists who are not practicing good investigative journalism - a dangerous combination. Furthermore, the public education being provided by the promoters of the fear narrative (e. g. by the White House Task Force on COVID and the conventional media) has primarily created counter-therapeutic fear, confusion, mystery, anxiety, loss of trust, polarization, animosity, and a feeling of loss of control - rather than respectful therapeutic demystification and empowerment.

- Bottom Line: COVID is a serious, potentially lifethreatening viral infection, primarily in the elderly and frail, and is quite communicable, but severe cases can be treated far more successfully than has been the case to date. Overall, there is insufficient scientific evidence to conclude that COVID represents a threat that is "far greater" than the worst seasonal flu epidemics we have experienced over the past 10 years (e. g. the 2017-2018 seasonal flu). Instead, the most scientifically sound data suggest that the intrinsic deadliness of the COVID virus is comparable to that of the 2017-2018 seasonal flu, possibly even less severe. Furthermore, many COVID deaths (and non-COVID deaths associated with this epidemic) could have been prevented by correcting the intrinsic deadliness of the health care system, nursing home model, general housing model, economic system, social system, and culture. Finally, the prolonged lockdown/re-lockdown approach appears to be mis-guided, unnecessary, and harmful. (More on this later.) It is dehumanizing and is not "following the science (i. e. good science)".

- We have little control over the intrinsic deadliness of the virus, but we have great control (if we choose to exercise it) over the intrinsic deadliness of the health care system, nursing home model, general housing model, economic system, social system, and culture. We also have control over the quality and rigor of our science, the quality of investigative journalism, the quality of our education of the Public (about COVID and associated social issues), and the quality of our Public Policy.

\section{AN ALTERNATIVE RESPONSE TO THE COVID EPIDEMIC}

Given what we now know about COVID, while realizing that there is still more to learn, how could we have responded more wisely, how could we now respond, and how might we prevent threatening epidemics in the future?

An initial, temporary, near-total lockdown was wise. It was a way to buy time, learn more, make plans, prepare hospitals and nursing homes, grab the public's attention, and educate and engage the public. That general lockdown, however, should probably have been kept in place for only about 2-3 weeks. And, the public education should have included: more than one narrative; careful distinction between assumption and fact; discussion of good-quality and poor-quality data; provision of context and perspective; and avoidance of sensationalistic journalism and creation of excessive fear.

\section{The Swedish Approach:}

Then, a plan similar to that deployed in Sweden could have been initiated [19]. The hallmarks of the Swedish plan, which is based on sound scientific epidemiologic and infectious disease principles and respectful education of the public, are to:

- Protect the Vulnerable - e. g. immediate near-total lockdown of nursing homes.

- Carefully allow the rest of the population to slowly but steadily develop collective Immunity ("herd" immunity) - while using common sense handwashing, respiratory etiquette, and at least temporary avoidance of close contact - encouraging common decency.

- Provide prompt, superb, bold, unrushed, free care to those who develop life-threatening versions of COVID - rapidly expanding ICU capacity, as needed. 
- Immediately initiate widespread accurate testing, honest data collection, honest public education, and development of public trust and cooperation. This includes establishment and application of uniform strict criteria for definite, probable, possible, and non-COVID death - so that an accurate COVID death count could be followed.

- Make sure that the health care system, nursing home model, housing model, economic system, and social system are not adversely contributing to disease communicability and death. This includes making factories and other workplaces as safe as possible. As of early May, Sweden has experienced more COVID deaths/capita than have other Nordic countries who have followed a plan of prolonged lockdown (if these nations are counting "COVID deaths" in comparable ways, which is a big "if") [19]. However, many of those Swedish deaths were due to regrettably slow implementation of protective measures in some Nursing Homes; and Sweden has had fewer COVID deaths/capita than Spain, Belgium, and the UK. In Sweden the median age of those who have died of COVID is 84 years [52]. As of early May, about $20-25 \%$ of the Stockholm population had developed antibodies to COVID, and this figure is anticipated to rise to over $50 \%$ in June [19]. In other words, Sweden is well on its way to developing collective immunity (which would probably require at least $60 \%$ of the population to have effective antibodies). This collective immunity, even if imperfect and ultimately shy of $60 \%$, will likely be at least partially protective against a "second wave" (and even a third wave) of COVID and will likely provide at least some cross-over protection against future problematic coronaviruses. Even the 20-25\% immunity has already been helping to at least slow the spread of the virus (thereby, "flattening the curve" in the Swedish way), and this will increasingly be the case as that percentage gradually rises. As a result, the Swedish population will most likely be better off over the long term than populations that have been prevented (via prolonged lockdown and re-lockdowns) from developing usual, natural collective immunity. (Incidentally, antibody studies in NYC have revealed that $27.6 \%$ of the Bronx population may now be antibody positive, despite lockdown efforts) [26]. It must be realized, however, that Sweden, unlike the USA, has a health care system and a social system that is designed to prevent unnecessary COVID deaths, while the USA has a health care system and social system that contribute to excessive, preventable COVID deaths.

The main difference between the Swedish approach and the USA approach is that the USA approach tries to prevent infection of not just the elderly and medi- cally vulnerable, but the rest of the population as well; whereas the Swedish approach tries to prevent infection of the elderly and medically vulnerable, but "allows" a slow, controlled, natural spread of infection among healthy people under age 60. The Swedish approach is not afraid to "allow" slow spread among healthy people under age 60, because: Evidence suggests that in this group the risk of dying from COVID infection is extremely small; most who do become infected will be either asymptomatic or only mild-moderately ill; those rare younger and previously healthy people who do become severely ill can be promptly and successfully treated (by aggressively suppressing their cytokine storm and other immune-mediated complications); and a pillar of the Swedish approach is to prevent this younger healthy population from having contact with the elderly and medically vulnerable (except for health care workers upon whom the elderly and medically vulnerable depend). The USA approach is extremely fearful of anyone becoming infected, even young healthy adults. The USA approach would be appropriate if COVID were as deadly as smallpox, but it is not. According to the USA approach, infection of any person, even a healthy person under age 60, represents a highly regrettable "failure", which would be true, if we were in the midst of a smallpox epidemic; whereas, according to the Swedish approach, infection of healthy people under age 60 is not a failure and, in fact, contributes to helpful collective immunity that ultimately helps to protect everyone, including the elderly and otherwise vulnerable.

The Swedish approach not only recognizes the futility of trying to forever prevent infection from developing among the healthy younger population, but also recognizes the short and long term benefits of carefully "allowing" natural collective immunity to slowly develop among the healthy younger population. The USA approach not only denies the benefits of collective immunity (including the benefits of partial collective immunity), but deliberately goes to extreme lengths to prevent natural collective immunity (via lockdown and re-lockdown). The USA approach does not acknowledge the futility, unsustainability, and life-threatening side effects of a prolonged lockdown/ re-lockdown approach; and commits society to recurrent re-lockdowns whenever "too many" new infections ("failures") occur.

The Swedish approach has nothing to do with "saving the economy", or "prioritizing the economy over people", or "sacrificing old people for the sake of the larger society". The Swedish approach has everything to do with "following good science" and preventing as many cumulative deaths as possible. While claiming to be scientific and caring about "saving lives", the 
USA approach is not scientifically sound and will likely prove to increase cumulative deaths (COVID deaths, non-COVID deaths, and "deaths of despair"), especially over the long term, globally, as well as in the USA.

Unfortunately, Sweden's thoughtful, compassionate, and science-based approach has been portrayed as "reckless", "careless", and "shamefully irresponsible" by many in the USA media. Sweden's approach has been thoughtful and caring and has followed the very best traditions of Medicine, Science, and Epidemiology. Sweden deserves to be praised and thanked, not shamed and demonized. It is possible (but unlikely) that Sweden will eventually be proven wrong; but, if so, it will not be because they have been careless and reckless. Sweden, correctly, has chosen to "follow the science (good science)", rather than follow poor science and proceed with fear, or neglect.

A Suggested Alternative Response to the Epidemic The response to COVID (in the USA and elsewhere) in the weeks and months ahead could be to:

- Continue to protect the vulnerable (e.g. those in nursing homes), by preventing them from becoming infected. The "vulnerable" includes workers in crowded, enclosed factories, where risks of rapid-spreading and exposure to larger viral loads are increased.

- Immediately correct the mistakes being made in the current reporting of "COVID deaths".

- Provide free testing of the population, using quality tests developed by excellent, reliable, not-for-profit, altruistic institutions.

- Allow the less vulnerable portion of the population (healthy people under age 65, or 60) to socialize, go to school, and participate in the economy, while responsibly taking common sense precautions and showing common decency - e.g. handwashing, respiratory etiquette, and temporary avoidance of close-contact settings. That is, permit careful, slow, but steady, controlled development of natural collective immunity - sufficiently slow and controlled to still protect the vulnerable.

- A cornerstone of the fear narrative is the rapid development of a vaccine. However, a truly safe and truly effective vaccine may not be possible for the COVID-19 virus, given the intrinsic nature of coronaviruses and influenza viruses (compared to measles, mumps, and rubella, e. g.) [7]. Because the COVID virus does not represent an extreme danger, and because it is difficult to assure safety and efficacy of such vaccines, it is debatable whether a vaccine for COVID is definitely necessary, safe, and warranted [7] - particularly a vaccine that has been rushed into production and use by profiteering pharmaceutical companies.
- Development of natural collective immunity is the best way to counter this epidemic and minimize deaths in the long run. Interference with development of collective immunity (by prolonged lockdown and re-lockdowns) will likely result in more cumulative COVID deaths and more non-COVID deaths over the long run. If certain countries choose the prolonged lockdown/re-lockdown approach, they must keep honest track of the excess non-COVID deaths that result from this policy (deaths from despair, deaths from poverty and hunger, deaths from inadequate attention to non-COVID health problems, etc.) Is the USA COVID Task Force making certain that these data (i. e. the potential side effects of their preferred narrative and plan) are being collected? A fundamental principle of Medicine is to collect data on the side effects of treatment - not to mention another fundamental principle of Medicine: Do no harm.

- Avoid creating cesspools of COVID virus in hospitals (and in nursing homes).

- Replace the current polarizing and fear-producing "public education" with true comprehensive public education and dialogue about COVID - a balanced education that respects the public; respects Humanity; respects diversity of opinion; provides and explains quality scientific data; carefully differentiates between assumption and fact; provides an accurate "COVID death" count; explains how the intrinsic deadliness of the USA health care system (and economic system, social system, nursing home model, etc.) contribute to COVID deaths; critically examines anecdotal observations and places them into perspective and context; explains nuance; encourages critical thinking; and discourages shaming and polarization.

- Maintain a running tally of the "deaths of despair" and deaths due to undertreated non-COVID illnesses (because of shutdown health services or fears about using them) that have occurred during and because of the prolonged lockdown. The Robert Graham Center for Policy Studies in Family Medicine and Primary Care has projected that somewhere between 75,000-150,000 "deaths of despair" (deaths from suicide, alcohol abuse, drug abuse, etc.) may occur during the COVID epidemic, as it is currently being handled. As of this writing (5/27/20), there have been 102,000 "COVID deaths".

- Create a new National COVID Task force: The current White House COVID Task Force has failed to follow many of the most fundamental and important principles of Medicine, Science, Epidemiology, and Public Policy. A new, more disciplined, more scientific, more objective, more inclusive, and more altruistic Task Force is needed - one with a diversity of views among its members - not just 
scientifically, but also regarding social philosophy, cultural background, economic philosophy, geo-political understanding, and appreciation of History. Since this is an international pandemic, and since USA decisions profoundly affect other countries, it would be good to have representatives from other countries on the Task Force.

- Create a new White House, with a new President: US citizens should consider replacing the current president with a person who has greater respect for science and has greater social compassion. Ideally, Mr. Trump could be replaced by someone who knows the difference (or is at least open to learning the difference) between "following sound science" and "following flawed science". Ideally, Mr. Trump could be replaced by someone who will not only repudiate "white supremacy", but also stop perpetuating the supremacist myths of "American Exceptionalism" and "American Indispensability". Ideally, Mr. Trump could be replaced by someone who will not execute the same NeoLiberal and Neo-Conservative Corporate Capitalist agenda, Wars, and other Crimes against Humanity that have been executed by all 12 Presidents who immediately preceded him. Ideally, he could be replaced by someone who recognizes the malignancy of Corporate Capitalism and is open to creation of new humanistic Social Arrangements, including free, comprehensive national health care and development of altruistic Public Economies. Ideally, he could be replaced by someone who deeply cares about Humanity and believes in Human Goodness.

- Invest heavily in immediate and long-term improvement of the health care system: reverse the decadeslong trend of shrinking the number of hospitals and clinics, particularly in rural areas where many hospitals have been closed; reverse the trend of privatizing health care; make health care accessible and free to everyone; eliminate profiteering throughout the health care system; and prepare hospitals with an abundance of ICU beds, negative pressure airflow rooms, PPEs, ample testing, needed medications, and preparation for best practice treatment of COVID (and future similar epidemics)

- Optimize treatment of those who become seriously ill with COVID [13, 32, 45]. Patients admitted to the ICU could be stratified and randomized to receive one of several appropriately aggressive protocols involving combination therapies. For example, one combination to consider for patients who are hypoxic and suffering from cytokine storm would be: - Remdesivir (possibly in combination with other anti-viral medications) - to interfere with viral replication [24].
- Interferon alpha $2 b$ - to induce an anti-viral state and further inhibit viral replication [24, 37, 48].

- IVIG [14] - to possibly block attachment of virus to receptors on human cells (?); and to help subdue an excessive immune response to the virus (which probably includes an immune-mediated occlusive microvascular endotheliopathy in the pulmonary microvasculature) $[1,2,4,23,53]$, being careful to avoid fluid overload.

- IV Anakinra - to block IL-1 and, thereby, shut down "cytokine storm". [11, 47, 54] (Tocilizum$\mathrm{ab}$, an anti-IL-6 agent, would be an alternative, but anakinra provides more flexibility $[10,30]$.)

- IV methylprednisolone - to further subdue immune over-reactivity [20].

- Heparinization to protect against micro- and macro-thrombosis [4].

- Note: Some patients may need all the above medications, in combination - either simultaneously, or with the anti-viral medications first, followed soon by the immunosuppressive therapies. Other patients may need only 2 or three of the above medications, in combination. To date, it appears as though the vast majority of patients who have died of COVID have not received even one of the above-mentioned antiviral/immunosuppressive medications, much less a combination. Astonishingly, Public education has not emphasized that medications like anakinra can be life-saving for those who develop cytokine storm.

- Keep hospitals and clinics open to serve COVID negative patients who have non-COVID health problems - by creating COVID-safe areas within each hospital, ideally with COVID antibody positive/PCR negative $\mathrm{HCW}$ (or at least PCR negative $\mathrm{HCW}$ who are being frequently re-tested) and screening patients before entry. This will prevent many of the unnecessary non-COVID deaths that are currently occurring because of a shutting down of many usual health care services.

- Correct the intrinsic deadliness of the current nursing home model, general housing model, economic model, and social model. (A short sentence, but huge need and task.) Prevent man-made social arrangements that create COVID "hotbeds" in certain nursing homes, inner city housing projects, factories, and certain communities (typically, communities of color).

- It is particularly important to correct the intrinsic deadliness of the current economic model - both in the health care economy and the general economy. There is need for healthy public dialogue as to whether there is any place for profiteering in health care -whether there is any place for profit motive, monetary incentive, "intellectual property rights", and 
patents in health care. Jonas Salk and Albert Sabin developed the polio vaccine without any interest in patenting or profiteering. Should Health Care be a solely altruistic Public Activity - with public hospitals and clinics, a public pharmaceutical industry, free health care, free nursing and medical education? Has this COVID epidemic not vividly demonstrated that private for-profit pharmaceutical companies, private health insurance companies, private hospital equipment companies, and the increasing privatization of health care have utterly failed the public?

- Has the COVID epidemic, particularly the results of the prolonged lockdown policy, not vividly demonstrated that the corporate capitalist economic model, including its billionaire philanthropists and foundations, has also utterly failed the public - particularly people of color, particularly the working class. After thorough public dialogue, would the public consider replacement of the current predatory corporate capitalist economic model with an altruistic and democratic Public Economy model?

- A fundamental principle of Medicine is to seek the root cause of problems: There is need to further explore the root cause of this epidemic:

- Was the appearance of this COVID virus due to a totally unpreventable random spontaneous mutation in nature that allowed a bat virus to "hop" to humans?

- Or, was the appearance of this virus due, largely, to preventable human activities that have harmed natural ecosystems, placed humans and animals in unnatural closeness, and facilitated the "hopping" of viruses from animals to humans? If so, we can correct this problem.

- Or, (in a spirit of taking an abundance of caution) should we not explore the possibility that this virus came from a Bioweapons/Biosecurity laboratory? Because, if so, there is a lot we could do to make sure such never happens again. Perhaps all Bioweapons laboratories, world-wide, should immediately be shut down, never to reopen - even if nothing nefarious has occurred to date. There is no reason why any healthy, pro-human research going on in such labs cannot be conducted, transparently, in altruistic academic labs. There is no need for secrecy, regarding prohuman research; and there should be no nefarious research - just like there should be no nuclear weapons. The new National COVID Task Force could assemble a diverse group of the world's best virologists and geneticists to objectively assess and definitively report whether the COVID virus was bio-engineered, or not, or whether it is impossible to know.
- What about COVID policies in other countries?

- It is important to honor the right of each country to decide for itself what would be best for its citizens, and how it can best contribute to a global response to a pandemic.

- Ideally, a nation's decisions should be made democratically; result from healthy national public dialogue; and be based on critical analysis of sound, scientific data, consideration of all plausible hypotheses, and information and advice provided by a diversity of expert opinions - taking the nation's unique conditions into consideration.

- In India, for example, it has been estimated that 3,290 children under age five die on a daily basis [28] - before COVID-19 ever arrived on the world scene. At the time of Modi's autocratic announcement of India's lockdown (on March 20), India had experienced 10 total deaths from COVID-19, probably all adults. After 2 months of lockdown, the cumulative "COVID death" count in India was 2,753 [55]. In the meantime, the lockdown has escalated misery in India [44]. To what extent has the daily death count of children (from non-COVID causes) increased during this lockdown? Does Modi know? Has he been keeping track? Are side effects of public policy not important? Are poverty-stricken children not important? Have parents in India been consulted?

- Physicians have an obligation to assess problems in the context of what is going on in the larger society. For example, if a pediatrician sees many children with lead poisoning, it is not enough to simply treat each individual child; the pediatrician must ask what is going on in society that allows the lead poisoning to happen. In this spirit, physicians and all citizens have a social obligation to at least ask who benefits (cui bono) from the prevailing narrative about the COVID epidemic. If the narrative is correct (that COVID is comparable to the horrific influenza A epidemic in 1918), then we all benefit from full awareness of this threat. If the narrative is not accurate, and if the prolonged lockdown/ re-lockdown response is unwise, then who, if anyone, benefits? We should be aware that during this epidemic, particularly because of the lockdown, a massive transfer of wealth, power, and control is occurring - from ordinary people to the already obscenely wealthy, powerful, and controlling.

- Finally, we all have an obligation to be kind to those who view things differently.

Unfortunately, hostility and intolerance have developed between those who support the narrative of fear and those who support the narrative of neglect. Some in the first camp categorize those who question their nar- 
rative as deplorable "deniers" and gullible "conspiracy theorists", who are "anti-science", anti-intellectual, have right wing tendencies (even subconsciously so), watch too much Fox News, listen to too much Rush Limbaugh, and are Trump-supporters (or, at best, Trump enablers) which is not only an unfair generalization, but incorrect. Some at the other end of the spectrum categorize all supporters of the narrative of fear as "elitists" who think they know best and condescendingly force their views on "the deplorables" - also, an unfair stereotyping. There is little, if any, dialogue between these two camps. Shaming, blaming, intolerance, ridicule, and hostility have tended to replace respectful dialogue.

Under-appreciated by many in both camps is the likelihood that the truth falls somewhere between these two ends of the spectrum - and that the most appropriate response to the COVID epidemic is a version of Sweden's careful middle ground approach.

Indeed, a main purpose of this article is to reduce the unhealthy polarization of views on COVID, by walking people from the extremes into the middle ground, where they can engage in respectful dialogue, understand each other, honor science, honor Humanity, constructively focus on the complex medical and social aspects of this epidemic, and work out a best remedy.

\section{THE SOCIAL RESPONSIBILITY OF CITIZENS; QUESTIONS TO ASK}

As nations deal with the COVID epidemic, their citizens, including their physicians, would be wise to notice whether:

"What the science tells us" is being accepted without critical examination of the quality of that "science"; journalistic sensationalism is replacing solid investigative journalism; "shaming" is replacing dialogue; assumptions are being portrayed as "accepted facts"; obedience and submission are replacing critical thinking; creation of public fear is replacing provision of accurate public education; fearful reaction is replacing calm analysis; challenging the preferred narrative is being dismissed as "misinformation" and "denial"; formulation of plausible hypotheses is being viewed as "engaging in conspiracy theories"; polarization and rigid black and white thinking is replacing appreciation of spectrum; mathematical modeling (rife with opaque assumptions, guesses, and biases) is replacing collection and analysis of quality data; altruism is being feared more than authoritarianism; the bigger geopolitical picture is being missed; and the citizenry is passively accepting a steady march toward a harmful form of medical martial law and a new global corporate form of authoritarianism (high-tech corporate fascism). Are any of the above happening?

Is the fear narrative correct? Have its primary promoters followed the disciplined problem-solving approach that has traditionally been practiced in the Medical Clinic? Is the fear narrative based on good science, quality data, ample evidence, and rigorous analysis of all plausible hypotheses? Is the narrative of neglect based on any science at all? Are these extreme narratives sufficiently comprehensive in their analyses? Do they respect Humanity? Are they genuinely committed to seeking truth? If so, how carefully, honestly, and competently have they done so - particularly considering the sloppy way in which "COVID deaths" have been determined and reported to the Public? Has the fear narrative been promoted by media that are practicing good investigative journalism? If the fear narrative, including its preferred response, is not accurate, how much harm is it doing? Is it "doing no harm"? Should we not ask, "Cui bono"? Considering what is at stake, should we not more carefully examine the accuracy of the fear narrative, the quality of the science and data behind it, the quality of investigative journalism promoting it, and the quality of public policy it has been encouraging - and have the courage to withstand the shaming of us for doing so?

If the primary promoters of the fear narrative have truly been concerned to determine truth, "follow the Science", and maximally save lives, then:

- Why did they not quickly establish and apply strict, clear, accurate criteria for definition of "COVID death"?

- Why did they not quickly roll out a quality testing effort?

- Why, with years of advanced warning of potential epidemics, including detailed preparatory exercises for them, were the hospitals, the health care system in general, and the country so ill-prepared?

- Why were policies not made to prevent "cesspools" of virus in some nursing homes and some hospitals?

- Why weren't greater efforts made to maintain health care services for patients with non-COVID problems?

- Why hasn't a greater effort been made to promptly and aggressively treat the most severely ill patients with COVID (with known treatments of cytokine storm and immune-mediated microvascular endothelipathy, e. g.)?

- Why were policies based so much on wild opaque mathematical projections (that only the mathematically gifted could critique), rather than collection of quality data (that most of the Public could easily understand)?

- Why has only one narrative and one solution (prolonged lockdown) been promoted and others belittled and scorned?

- Why have all plausible explanations of observed anecdotal phenomena not been considered, thoroughly investigated, and publicly discussed? 
- Why has there not been more careful distinction between assumption and fact?

- Why has public education been so one-sided, scientifically sloppy, confusing, mystifying, fearproducing, and demoralizing?

- Why has there been so little effort to study the side effects of the prolonged lockdown approach (e. g. collection of data regarding non-COVID deaths resulting from this approach, including deaths of despair)?

- Why has the prevailing narrative chosen a remedy (prolonged lockdown) that deliberately interferes with and scorns the slow, controlled, beneficial development of natural collective immunity?

- In short, if the goal has truly been to determine truth, "follow the science", and maximally save lives, why have the most important fundamental principles of Medicine, Science, Epidemiology, Public Policy, and Investigative Journalism not been followed?

The COVID-19 virus has exposed the intrinsic deadliness of many aspects of the current social system (at least in the USA). It is revealing that the Empire has no clothes! In addition to focusing on the virus, we have an obligation to focus sharply on creation of a far better health care system, a far better pharmaceutical system, a far better economic system (Public Economy?), a far better nursing home system, a far better housing and social system, and a far better culture. Our response to this epidemic should not be limited to developing a vaccine and other anti-viral therapies. It should focus primarily on correction of the intrinsically deadly aspects of current Social Arrangements - man-made aspects, over which we have control.

If this Additional (scientific, public-oriented) Narrative is correct (and I think it is), we have a choice. We can allow the currently prevailing fear narrative to lead us into a future of increasingly authoritarian, undemocratic, cold, sterile, high-tech, corporatized, Global Surveillance Capitalism - a future of FEAR, job insecurity, cruel austerity, and indebtedness. Or, we can recognize the Trump presidency and the fear narrative as needed catalysts that have provided clarifying evidence that it is time to democratically develop a new set of Social Understandings and Social Arrangements.

Perhaps the best overall response to the COVID epidemic is to do all we can to try to create Social Beauty and avoid passive acceptance of an inadequately examined march toward its opposite?

\section{REFERENCES}

1. Ackermann M, Verleden SE, Kuehnel M, et al. Pulmonary Vascular Endothelialitis, Thrombosis, and Angiogenesis in Covid-19. N Engl J Med. 2020. https://doi. org/10.1056/NEJMoa2015432.
2. Agamanolis DP, Prayson RA, Asdaghi N, et al. Brain microvascular pathology in Susac syndrome: an electron microscopic study of five cases. Ultrastruct Pathol. 2019;43(6):229-236. https://doi.org/10.1080/0191 3123.2019.1692117.

3. Axelrod J. CBS News, March 2, 2020: coronavirus may infect up to $70 \%$ of world's population, expert warns. www.cbsne ws.com [Internet]. [cited 2020 Mar 4]. Available from: https://www.cbsne ws.com/news/ coronavirus-infection-outbreak-worldwide-virus -expert-warning-today-2020-03-02/.

4. Becker RC. COVID-19 update: Covid-19-associated coagulopathy. J Thromb Thrombolysis. 2020;50(1): 54-67. https://doi.org/10.1007/s11239-020-02134-3.

5. Bhakdi S. Corona-Krise: Prof. Sucharit Bhakdi erklärt warum die Mafsnahmen sinnlos und selbstzerstörerisch sind - YouTube. www.youtube.com [Internet]. [cited 2020 May 23]. Available from: https://www. youtube.com/watch? $v=J B B 9 b A-g X L 4$.

6. Bhakdi S. Doctor Sucharit Bhakdi Challenges the Coronavirus Crisis. newyorkcityguns.com [Internet]. [cited 2020 May 23]. Available from: https://newyorkcityguns.com/professor-doctor-sucharit-bhakdichallenges-the-coronavirus-crisis/.

7. Bhakdi S. Endless Corona Madness? A Talk with Prof. Dr. Sucharit Bhakdi - Servus TV. servustv.com [Internet]. [cited 2 May 2020]. Available from: https:// www.servustv.com/videos/aa-23zjmvcz51w12/.

8. Bhimraj A, Morgan RL, Shumaker AH, et al. Infectious Diseases Society of America Guidelines on the Treatment and Management of Patients with COVID-19. Clin Infect Dis. 2020. https://doi.org/10.1093/cid/ ciaa478.

9. Boom V, Anton J, Lahdenne P, et al. Evidence-based diagnosis and treatment of macrophage activation syndrome in systemic juvenile idiopathic arthritis. Pediatr Rheumatol Online J. 2015;13:55. https://doi. org/10.1186/s12969-015-0055-3.

10. Capra R, De Rossi N, Mattioli F, et al. Impact of low dose tocilizumab on mortality rate in patients with COVID-19 related pneumonia. Eur J Intern Med. 2020;76:31-35. https://doi.org/10.1016/j.ejim.2020.05.009.

11. Cavalli G, De Luca G, Campochiaro C, et al. Interleukin-1 blockade with high-dose anakinra in patients with COVID-19, acute respiratory distress syndrome, and hyperinflammation: a retrospective cohort study. Lancet Rheumatol. 2020;2(6): e325-e331. https://doi. org/10.1016/s2665-9913(20)30127-2.

12. CDC; 2020. CDC Estimated Influenza Illnesses, Medical visits, Hospitalizations, and Deaths in the United States - 2017-2018 influenza season. www.cdc.gov [Internet]. [cited 2020 May 23]. Available from: https://www.cdc.gov/flu/about/ burden/2017-2018.htm. 
13. Coperchini F, Chiovato L, Croce L, et al. The cytokine storm in COVID-19: An overview of the involvement of the chemokine/chemokine-receptor system. Cytokine Growth Factor Rev. 2020;53:25-32. https://doi. org/10.1016/j.cytogfr.2020.05.003.

14. Diez JM, Romero C, Gajardo R. Currently available intravenous immunoglobulin contains antibodies reacting against severe acute respiratory syndrome coronavirus 2 antigens. Immunotherapy. 2020;12(8):571-576. https://doi.org/10.2217/imt-2020-0095.

15. Rajgor DD, Lee MH, Archuleta S, et al. The many estimates of the COVID-19 case fatality rate. Lancet Infect Dis. 2020;20(7):776-777. https://doi.org/10.1016/ s1473-3099(20)30244-9.

16. Dong Y, Mo X, Hu Y, et al. Epidemiology of COVID-19 Among Children in China. Pediatrics. 2020;145(6). https://doi.org/10.1542/peds.2020-0702.

17. Ferguson N. Fellowships/Imperial-College-COVID19NPI-modelling-16-03-2020.pdf. imperial.ac.uk [Internet]. [cited 2020 May 23]. Available from: https:// www.imperial.ac.uk/media/imperial-college/medicine/sph/ide/gida.

18. Ghebreyesus TA. who.int [Internet]. [cited 2020 May 23]. Available from: https://www.who.int/dg/speeches/detail/who-director-general-sopening-remarks-at-themedia-briefing-on-covid-19-3-March-2020/.

19. Gieseke J. The Invisible Pandemic. The Lancet. 2020; May 5. Also, see the Chatham House Webinar: Weekly COVID-19 Pandemic Briefing - The Swedish Approach, an interview of Johan Giesecke. youtube.com [Internet]. [cited 2020 May 23]. Available from: https:// www.youtube.com/watch?v=LAT660jarGA.

20. Goursaud S, Descamps R, Daubin C, et al. Corticosteroid use in selected patients with severe acute respiratory distress syndrome related to COVID-19. J Infect. 2020. https://doi.org/10.1016/j.jinf.2020.05.023.

21. Gudbjartsson DF, Helgason A, Jonsson $H$, et al. Spread of SARS-CoV-2 in the Icelandic Population. N Engl J Med. 2020;382(24):2302-2315. https://doi. org/10.1056/NEJMoa2006100.

22. He D, Zhao S, Lin Q, et al. The relative transmissibility of asymptomatic COVID-19 infections among close contacts. Int J Infect Dis. 2020;94:145-147. https:// doi.org/10.1016/j.ijid.2020.04.034.

23. Zeng H, Pappas C, Belser JA, et al. Human pulmonary microvascular endothelial cells support productive replication of highly pathogenic avian influenza viruses: possible involvement in the pathogenesis of human H5N1 virus infection. J Virol. 2012;86(2): 667-678. https://doi.org/10.1128/JVI.06348-11.

24. Hung IF-N, Lung K-C, Tso EY-K, et al. Triple combination of interferon beta-1b, lopinavirritonavir, and ribavirin in the treatment of patients admitted to hospital with COVID-19: an open-label, randomised, phase 2 trial. Lancet. 2020;395(10238):1695-1704. https://doi.org/10. 1016/s0140-6736(20)31042-4.

25. Ioannidis JPA. Coronavirus disease 2019: The harms of exaggerated information and non-evidence-based measures. Eur J Clin Invest. 2020;50(4): e13222. https://doi.org/10.1111/eci.13222.

26. medrxiv.org [Internet]. loannidis J. The infection fatality rate of COVID-19 inferred from seroprevalence data [cited 2020 May 23]. Available from: https://www.medrxiv.org/content/10.1101/2020.05.13.20101253v2.

27. Keshavarz M, Namdari H, Farahmand M, et al. Association of polymorphisms in inflammatory cytokines encoding genes with severe cases of influenza A/H1N1 and $B$ in an Iranian population. Virol J. 2019;16(1):79. https://doi.org/10.1186/s12985-019-1187-8.

28. Liu L, Chu Y, Oza S, et al. National, regional, and statelevel all-cause and cause-specific under-5 mortality in India in 2000-15: a systematic analysis with implications for the Sustainable Development Goals. Lancet Glob Health. 2019;7(6): e721-e734. https://doi. org/10.1016/S2214-109X(19)30080-4.

29. Liu Y, Gayle AA, Wilder-Smith A, Rocklov J. The reproductive number of COVID-19 is higher compared to SARS coronavirus. J Travel Med. 2020;27(2). https:// doi.org/10.1093/jtm/taaa021.

30. Magro G. SARS-CoV-2 and COVID-19: is interleukin-6 (IL-6) the 'culprit lesion' of ARDS onset? What is there besides Tocilizumab? SGP130Fc. Cytokine X. 2020:100029. https://doi.org/10.1016/j.cytox.2020.100029.

31. Mehta P, Cron RQ, Hartwell J, et al. Silencing the cytokine storm: the use of intravenous anakinra in haemophagocytic lymphohistiocytosis or macrophage activation syndrome.Lancet Rheumatol.2020;2(6):e358-e367. https:// doi.org/10.1016/s2665-9913(20)30096-5.

32. Mehta P, McAuley DF, Brown M, et al. COVID-19: consider cytokine storm syndromes and immunosuppression. Lancet. 2020;395(10229):1033-1034. https:// doi.org/10.1016/s0140-6736(20)30628-0.

33. Mein SA. COVID-19 and Health Disparities: the Reality of "the Great Equalizer". J Gen Intern Med. 2020. https://doi.org/10.1007/s11606-020-05880-5.

34. Merad M, Martin JC. Pathological inflammation in patients with COVID-19: a key role for monocytes and macrophages. Nat Rev Immunol. 2020;20(6):355-362. https://doi.org/10.1038/s41577-020-0331-4.

35. Millett GA, Jones AT, Benkeser D, et al. Assessing Differential Impacts of COVID-19 on Black Communities. Ann Epidemiol. 2020. https://doi.org/10.1016/j.annepidem.2020.05.003.

36. Nicastri E, Petrosillo N, Ascoli Bartoli T, et al. National Institute for the Infectious Diseases “L. Spallanzani”, IRCCS. Recommendations for COVID-19 clinical man- 
agement. Infect Dis Rep. 2020;12(1):8543. https:// doi.org/10.4081/idr.2020.8543.

37. Nile SH, Nile A, Qiu J, et al. COVID-19: Pathogenesis, cytokine storm and therapeutic potential of interferons. Cytokine Growth Factor Rev. 2020;53:66-70. https://doi.org/10.1016/j.cytogfr.2020.05.002.

38. Poteat T, Millett G, Nelson LE, Beyrer C. Understanding COVID-19 Risks and Vulnerabilities among Black Communities in America: The Lethal Force of Syndemics. Ann Epidemiol. 2020. https://doi.org/10.1016/j. annepidem.2020.05.004.

39. Qin C, Zhou L, Hu Z, et al. Dysregulation of immune response in patients with COVID-19 in Wuhan, China. Clin Infect Dis. 2020. https://doi.org/10.1093/cid/ ciaa248.

40. Reynolds E. The world sacrificed its elderly in the race to protect hospitals. The result was a catastrophe in care homes - CNN. cnn.com [Internet]. [cited 2020 May 26]. Available from: https://www.cnn. com/2020/05/26/world/elderly-care-homes-coronavirus-intl/index.html.

41. Robert Koch Institut. Bericht zur Epidemiologie der Influenza in Deutschland Saison 2017/18. Robert Koch-Institut; 2018. influenza.rki.de [Internet]. [cited 2020 May 26]. Available from: https://influenza.rki. de/Saisonberichte/2017.pdf.

42. Qu R, Ling Y, Zhang YH, et al. Platelet-to-lymphocyte ratio is associated with prognosis in patients with coronavirus disease-19. J Med Virol. 2020. https://doi. org/10.1002/jmv.25767.

43. Roussel Y, Giraud-Gatineau A, Jimeno M-T, et al. SARS-CoV-2: fear versus data. International Journal of Antimicrobial Agents. 2020 May; 55(5). https://doi. org/10.1016/j.ijantimicag.2020.105947.

44. Roy A. Arundhati Roy on Indian Migrant-Worker Oppression and India's Fateful COVID Crisis. counterpunch.org [Internet]. [cited 24 May 2020]. Available from: https://www.counterpunch.org/2020/05/29/ arundhati-roy-on-indian-migrant-worker-oppression-and-indias-fateful-covid-crisis/.

45. Saghazadeh A, Rezaei N. Towards treatment planning of COVID-19: Rationale and hypothesis for the use of multiple immunosuppressive agents: Antiantibodies, immunoglobulins, and corticosteroids. Int Immunopharmacol. 2020;84:106560. https://doi. org/10.1016/j.intimp.2020.106560.
46. Scott D. Coronavirus Case Fatality Rates in US and Singapore. vox.com [Internet]. [cited 24 May 2020]. Available from: https://www.vox.com/ 2020/5/20/21265194/coronavirus-deaths-us-singapore-case-fatality-rates.

47. Shakoory B, Carcillo JA, Chatham WW, et al. Interleukin-1 Receptor Blockade Is Associated With Reduced Mortality in Sepsis Patients With Features of Macrophage Activation Syndrome: Reanalysis of a Prior Phase III Trial. Crit Care Med. 2016;44(2):275-281. https://doi.org/10.1097/CCM.0000000000001402.

48. Shalhoub S. Interferon beta-1b for COVID-19. Lancet. 2020;395(10238):1670-1671. https://doi.org/ 10.1016/s0140-6736(20)31101-6.

49. Shekerdemian LS, Mahmood NR, Wolfe KK, et al. Characteristics and Outcomes of Children With Coronavirus Disease 2019 (COVID-19) Infection Admitted to US and Canadian Pediatric Intensive Care Units. JAMA Pediatr. 2020. https://doi.org/10.1001/jamapediatrics.2020.1948.

50. Yang S, Cao P, Du P, et al. Early estimation of the case fatality rate of COVID-19 in mainland China: a data-driven analysis. Ann Transl Med. 2020;8(4):128. https://doi.org/10.21037/atm.2020.02.66.

51. Streeck H, Schulte B, Kuemmerer B, et al. Infection fatality rate of SARS-CoV-2 infection in a German community with a super-spreading event. medRxiv. 2020. https://doi.org/10.1101/2020.05.04.20090076.

52. Swiss Propaganda Research. Studies on COVID-19 Lethality. globalresearch.ca [Internet]. [cited 2020 May 25]. Available from: https://www.globalresearch. $\mathrm{ca} /$ studies-covid-19-lethality/5713991.

53. Tian S,Xiong Y, Liu H, et al. Pathological study of the 2019 novel coronavirus disease (COVID-19) through postmortem core biopsies. Mod Pathol. 2020;33(6):1007-1014. https://doi.org/10.1038/s41379-020-0536-x.

54. Wohlfarth $P$, Agis $H$, Gualdoni GA, et al. Interleukin 1 Receptor Antagonist Anakinra, Intravenous Immunoglobulin, and Corticosteroids in the Management of Critically IIL Adult Patients with Hemophagocytic Lymphohistiocytosis. I Intensive Care Med. 2019;34(9):723-731. https://doi.org/10.1177/ 0885066617711386.

55. Worldometer; 2020. worldometers.info [Internet]. [cited 2020 May 27]. Available from: https://www. worldometers.info/coronavirus/\#countries.
- Information about the author

Robert Rennebohm - MD, Visiting Professor. Department of Hospital Pediatrics St. Petersburg State Pediatric Medical University, Saint Petersburg, Russia. E-mail: rmrennebohm@ gmail.com.
- Информация об авторе

Роберт Реннебом - приглашенный профессор, кафедра госпитальной педиатрии. ФГБОУ ВО «Санкт-Петербургский государственный педиатрический медицинский университет» Минздрава России, Санкт-Петербург. E-mail: rmrennebohm@gmail.com. 